\title{
Genderneutrale tekst - wel of niet doen?
}

\author{
Ineke Maas
}

MEM 93 (2): 107-109

DOI: 10.5117/MEM2018.2.MAAS

Sinds enige tijd worden in de Volkskrant de beroepen en functies van mannen en vrouwen aangeduid met een genderneutrale term. Over het algemeen komt deze overeen met wat vroeger de mannelijke variant was. Er wordt dus gesproken over de student, leraar, voetballer en schrijver ongeacht of de betreffende persoon een man of vrouw is (of zich wellicht met geen van beide identificeert). Als er geen 'neutrale' term voor een beroep is, zoals bijvoorbeeld bij secretaresse, dan moet deze aanduiding worden vermeden en worden vervangen door een neutrale term, in dit geval managementassistent. Ik vermoed dat de gedachte achter deze schrijfregel is dat het er niet toe doet of iemand een man of vrouw is, het gaat om wat hij of zij doet of zegt. Een lovenswaardige gedachte, maar werkt het ook zo?

Om maar met de conclusie te beginnen: ik denk dat het niet zo werkt. Een leraar en een managementassistent associeer ik met een man en een secretaresse associeer ik met een vrouw. Genderneutrale terminologie versterkt, naar mijn mening, de vooroordelen met betrekking tot de taakverdeling in de maatschappij. Natuurlijk, de lezer kan in een artikel ook vinden hoe de betreffende persoon heet en naar mannen wordt met 'hij' verwezen en naar vrouwen met 'zij', maar dit gebeurt vaak niet in de koppen en het kan een vlugge lezer snel ontgaan.

Het is best vreemd dat ik als hoogopgeleide fulltime werkende vrouw die zelf onderzoek doet naar sekseongelijkheid zulke 'ouderwetse' associaties bij mijzelf vaststel. Ben ik nu zo uitzonderlijk? Helaas niet, het komt vaker voor, ook onder andere sociaalwetenschappers. Onlangs was ik lid van een promotiecommissie en ontving ik een uitnodiging voor de verdediging. De uitnodiging bevatte ook instructies wat betreft de kleding die de leden van de commissie geacht werden te dragen bij de ceremonie: 'The professors wear a gown and a cap. Under it, a dark suit, white shirt and dark tie and black shoes (no jeans or sneakers please). Associate professors 
wear a dark suit, a white shirt, a dark tie and black shoes.' Bij navraag bleek dit geen blindelings gekopieerde zin uit een standaarduitnodiging te zijn, maar een speciaal voor deze gelegenheid geformuleerde tekst. Het was de promotores niet opgevallen dat deze omschrijving niet zo van toepassing was op vrouwelijke leden van de commissie. Een collega vertelde me een soortgelijke anekdote. Zij werd, als vrouw in een verder geheel uit mannen bestaande leescommissie, door een hoogleraar van buiten prompt voor de pedel aangezien.

Soms nemen de genderspecifieke associaties een iets subtielere vorm aan. Onlangs checkte de Volkskrant (17-3-2018) de stelling dat jongens meer zakgeld krijgen dan meisjes. Daar bleek iets van waarheid in te zitten. Hoewel niet altijd en overal, lieten sommige onderzoeken zien dat jongens gemiddeld een groter bedrag krijgen dan meisjes. Een verklaring die door een expert werd geopperd is dat meisjes vaker met hun moeder gaan winkelen. De moeder betaalt dan de kleding voor het meisje. Om dat te compenseren zouden jongens meer zakgeld krijgen. Op het eerste gezicht lijkt dit best plausibel. Je ziet voor je hoe moeder en dochter gezellig winkelen en hoe zoonlief desgevraagd zegt dat hij niet mee wil. Maar als je even verder doordenkt lijkt dit toch te snel geconcludeerd. Het suggereert dat jongens nooit met hun moeder - of vooruit met hun vader - iets ondernemen waarbij de ouder betaalt. In de zomer wemelt het van de jongens met dure voetbalshirts. Zouden ze die echt allemaal van hun zakgeld bij elkaar hebben gespaard? Ik weet het natuurlijk niet, maar op zijn best moet hier nog verder onderzoek naar worden gedaan.

En soms is alle subtiliteit zoek. In strijd met de wet stelde de baas van Schiphol dat zijn opvolger een man moest zijn, omdat er anders in het bestuur een meerderheid van vrouwen zou ontstaan. Het ging niet om het volledig ontbreken van mannen in het bestuur (een gebrek aan diversiteit), maar om een scheve verhouding. Hier lijkt het besturen van een groot bedrijf wel heel sterk te worden geassocieerd met mannelijkheid. De mogelijkheid dat zich een excellente vrouwelijke kandidaat zou aandienen waardoor de kwaliteit van het bestuur (bij zijn vertrek) omhoog zou gaan, lijkt niet bij de baas op te komen.

Bij al deze voorbeelden worden vrouwen geassocieerd met minder aantrekkelijke posities. Het omgekeerde bestaat echter ook. Al te vaak wordt er vanzelfsprekend vanuit gegaan dat misdadigers mannen zijn. Ook dit vooroordeel wordt versterkt als alle personen die een overtreding begaan consistent met een mannelijke term worden aangeduid. Ik zocht in LexisNexis in de Volkskrant van de eerste drie maanden van 2018, maar vond geen enkele misdadigster, inbreekster, zakkenrolster of dievegge. De mannelijke 
varianten kwamen alle meermaals voor. Het is wel zo dat er aanzienlijk meer mannen dan vrouwen de wet overtreden, maar een vrouw die inbreekt is daardoor ook weer nieuwswaardiger dan een man die datzelfde doet. Mogelijk waren dus sommige van die misdadigers vrouwen, maar ze zijn met een mannelijk (ofwel neutraal) label aangeduid.

Bij het lezen van de Volkskrant viel me al op dat ook de verslaggevers zelf niet aan vooroordelen ontkomen. In één en hetzelfde artikel werd de ene vrouwelijke $\mathrm{PhD}$-student aangeduid als $\mathrm{PhD}$-student, maar de volgende als $\mathrm{PhD}$-studente. Ik interpreteer de eerste als poging de regel te volgen en de tweede als slip of the pen. Wat verder zoeken met LexisNexis levert op hoe moeilijk het is om consistent te zijn. Alle bakkers worden aangeduid met bakker en alle onderzoeksleiders met onderzoeksleider. Tegenover 125 keer kok staat 1 keer kokkin. Er is echter 466 keer sprake van schrijver en 54 keer van schrijfster. Dit is blijkbaar een uitzondering op de regel. Maar waarom? Nog moeilijker lijkt het te zijn in gevallen waar aantoonbaar meer vrouwen dan mannen een bepaald beroep uitoefenen. Tegenover 15 verpleegsters staan 12 verplegers.

Ik denk dat $\mathrm{u}$ het met mij eens bent dat vooroordelen over taakverdeling tussen mannen en vrouwen in de maatschappij nog veel voorkomen. Dergelijke vooroordelen kunnen volgens mij beter bestreden worden door heel expliciet te benoemen of een taak wordt uitgevoerd door een man of een vrouw. Dus: voorzitster, onderzoeksleidster en studente, maar ook inbreekster en verpleger. Alleen op die manier leren we hoeveel uitzonderingen op de regel er al zijn. 
